\title{
Complement Mediated Hemolytic Anemias in the COVID-19 Era: Case Series and Review of the Literature
}

\section{OPEN ACCESS \\ Edited by:}

Nicolas Stephane Merle, National Heart, Lung, and Blood Institute (NHLBI), United States

Reviewed by: Ronald Paul Taylor, University of Virginia, United States

Marie-Agnes Dragon-Durey, Université Paris Descartes, France

*Correspondence:

Austin G. Kulasekararaj austin.kulasekararaj@nhs.net

Specialty section:

This article was submitted to Molecular Innate Immunity, a section of the journal

Frontiers in Immunology

Received: 08 October 2021 Accepted: 29 October 2021 Published: 25 November 2021

Citation:

Fattizzo $B$, Pasquale $R$, Bellani $V$, Barcellini $W$ and Kulasekararaj $A G$ (2021) Complement Mediated

Hemolytic Anemias in the COVID-19 Era: Case Series and Review of the Literature. Front. Immunol. 12:791429. doi: 10.3389/fimmu.2021.791429

\author{
Bruno Fattizzo $^{1,2}$, Raffaella Pasquale ${ }^{2}$, Valentina Bellani ${ }^{1,2}$, Wilma Barcellini ${ }^{1}$ \\ and Austin G. Kulasekararaj ${ }^{3 *}$ \\ 1 Hematology Unit, Fondazione IRCCS Ca' Granda Ospedale Maggiore Policlinico, Milan, Italy, ${ }^{2}$ Department of Oncology \\ and Hemato-Oncology, University of Milan, Milan, Italy, ${ }^{3}$ Hematology Unit, King's College Hospital, London, United Kingdom
}

The complex pathophysiologic interplay between SARS-CoV-2 infection and complement activation is the subject of active investigation. It is clinically mirrored by the occurrence of exacerbations of complement mediated diseases during COVID-19 infection. These include complement-mediated hemolytic anemias such as paroxysmal nocturnal hemoglobinuria $(\mathrm{PNH})$, autoimmune hemolytic anemia $(\mathrm{AlHA})$, particularly cold agglutinin disease (CAD), and hemolytic uremic syndrome (HUS). All these conditions may benefit from complement inhibitors that are also under study for COVID-19 disease. Hemolytic exacerbations in these conditions may occur upon several triggers including infections and vaccines and may require transfusions, treatment with complement inhibitors and/or immunosuppressors (i.e., steroids and rituximab for $\mathrm{AlHA}$ ), and result in thrombotic complications. In this manuscript we describe four patients (2 with $\mathrm{PNH}$ and 2 with CAD) who experienced hemolytic flares after either COVID-19 infection or SARS-Cov2 vaccine and provide a review of the most recent literature. We report that most episodes occurred within the first 10 days after COVID-19 infection/vaccination and suggest laboratory monitoring ( $\mathrm{Hb}$ and $\mathrm{LDH}$ levels) in that period. Moreover, in our experience and in the literature, hemolytic exacerbations occurring during COVID-19 infection were more severe, required greater therapeutic intervention, and carried more complications including fatalities, as compared to those developing after SARS-CoV-2 vaccine, suggesting the importance of vaccinating this patient population. Patient education remains pivotal to promptly recognize signs/symptoms of hemolytic flares and to refer to medical attention. Treatment choice should be based on the severity of the hemolytic exacerbation as well as of that of COVID-19 infection. Therapies include transfusions, complement inhibitor initiation/additional dose in the case of $\mathrm{PNH}$, steroids/rituximab in patients with CAD and warm type AlHA, plasma exchange, hemodialysis and complement inhibitor in the case of atypical HUS. Finally, anti-thrombotic prophylaxis should be always considered in these settings, provided safe platelet counts.

Keywords: paroxysmal nocturnal hemoglobinuria, cold agglutinin disease, SARS-CoV-2, COVID19 vaccine, hemolytic uremic syndrome, autoimmune hemolytic anemia 


\section{INTRODUCTION}

There is an increasing interest in the relationship between COVID-19 infection and complement activation. Several reports highlighted that the virus is able to induce an over inflammatory state encompassing the activation of various pathways such as coagulation (namely thrombo-inflammation) and the complement cascade (1-3). The latter is a complex system which may be activated by three different ways: the classical, the lectin and the alternative pathway. The former two require the presence of a specific trigger, either an immune-complex or an infectious agent. The complement alternative pathway is homeostatically active and its functioning may be amplified in the presence of triggers. Complement-mediated hematologic diseases include paroxysmal nocturnal hemoglobinuria (PNH), autoimmune hemolytic anemia (AIHA), particularly cold agglutinin disease (CAD), and hemolytic uremic syndrome (HUS). PNH is caused by the acquisition of somatic mutation of PIG-A gene resulting in the loss of glycosylphosphatidylinositolanchored proteins, including the complement inhibitors CD55 and CD59. PNH cells are therefore subject to complementmediated destruction that mainly involves erythrocytes with consequent hemolytic anemia. PNH is managed successfully with terminal complement inhibitors targeting C5 (eculizumab or ravulizumab) with good control of intravascular hemolysis (IVH), but potentially inducing iatrogenic extravascular hemolysis $(\mathrm{EVH})$ which is targeted by novel C3 inhibitors (4). CAD is an autoimmune hemolytic anemia caused by cold reactive antierythrocyte autoantibodies usually of the IgM class that are intrinsically able to fix complement with consequent positivity of the direct antiglobulin test (DAT) for C3d (5). This may result in both IVH and EVH due to either terminal activation of complement and membrane attack complex (MAC) formation, or $\mathrm{C} 3 \mathrm{~b}$ deposition on erythrocytes and reticulo-endothelial phagocytosis. $\mathrm{CAD}$ is mainly treated with immunosuppressants (steroids and the anti-CD20 monoclonal antibody rituximab) and complement inhibitors are in clinical trials with promising results (6). Complement activation may be observed even in warm type AIHA (wAIHA), particularly in case of high levels of IgG antierythrocyte autoantibodies, resulting in DAT positivity for IgG+C. $\mathrm{IgG}+\mathrm{C}$ wAIHAs are generally more severe and show higher relapse frequency. Clinical trials with complement inhibitors in wAIHA are also ongoing (7). HUS is a thrombotic microangiopathy characterized by the formation of platelet microthrombi in arterioles and capillaries, causing platelet consumption, nonimmune hemolytic anemia, and acute renal injury. Typical HUS is caused by Shiga-like toxin (verotoxin) produced by Escherichia coli (O157: H7) and Shiga toxin by Shigella dysenteriae. The atypical form may be secondary to bacteria, medication, or immune processes capable of endothelial damage, or to congenital or acquired conditions inducing widespread complement activation, such as atypical familial HUS. In the latter cases C5 inhibitors are employed with clinical benefit (8). All these complement-mediated hemolytic conditions may experience exacerbations upon several triggers including infections, surgery, traumas $(4,5)$. Particularly, hemolytic flares in PNH patients on complement inhibitors are denominated breakthrough hemolysis (BTH) (4). COVID19 infection and its vaccine are also possible triggers through various mechanisms including lectin- and alternative pathway activation by Nucleocapside and Spike viral proteins, molecular mimicry and autoantibody production with activation of the classical pathway, etc (1). In this manuscript we describe four patients who experienced PNH BTH and CAD exacerbation after either COVID infection or SARS-Cov2 vaccine and we review the most recent literature.

\section{METHODS}

We report four patients, 2 with PNH and 2 with CAD, diagnosed according to the current guidelines $(4,5)$ and regularly followed at a tertiary university hospital in Milan, Italy, who experienced hemolytic flares during COVID-19 infection or after SARS-CoV2 vaccine.

The study was conducted according the Declaration of Helsinki and approved by the local Ethical Committee. Patients signed informed consent.

We conducted a review of the literature about complement mediated hemolytic anemias and COVID-19 infection and SARS-CoV-2 vaccine by searching for indexed articles and published abstracts until September 2021 in MEDLINE via PubMed and the National Library of Medicine. The following keywords were used: paroxysmal nocturnal hemoglobinuria; cold agglutinin disease; SARS-CoV-2; COVID19 vaccine; hemolytic uremic syndrome; autoimmune hemolytic anemia; and complement. We selected only studies including human subjects with a clear diagnosis of PNH, CAD, AIHA, HUS, and reporting data on treatment and outcome of COVID-19 infection and of the hemolytic flare.

\section{RESULTS}

\section{PNH Flares During COVID-19 Infection Case Description}

A 27-year-old man was diagnosed with PNH in 2010 (granulocyte clone size $93 \%)$ associated with transfusion dependent anemia $(\mathrm{Hb}$ $6.8 \mathrm{~g} / \mathrm{dL}, \mathrm{LDH} 7.5 \mathrm{x}$ upper limit of normality, ULN, PLT $121 \times 10^{9} / \mathrm{L}$, neutrophils $1.8 \times 10^{9} / \mathrm{L}$, reticulocytes $121 \times 10^{9} / \mathrm{L}$ ) and symptoms of hemolysis with abdominal pain. He was immediately started on eculizumab $900 \mathrm{mg}$ fortnightly with good response $(\mathrm{Hb} 11.1 \mathrm{~g} / \mathrm{dL}$, LDH 1.1xULN, reticulocytes 51x10/L). In March 2021, a nasopharyngeal swab for SARS-Cov-2 performed for screening purposes was positive and the patient was initially asymptomatic. Two days later, he presented to the emergency room complaining of shortness of breath, asthenia, and dark urine. $\mathrm{Hb}$ was $6.1 \mathrm{~g} / \mathrm{dL}$ and LDH increased to $10.7 \mathrm{x}$ ULN. A CT scan revealed bilateral interstitial pneumonia and he was admitted to hospital and treated with antibiotics, dexamethasone, and low molecular weight heparin (LMWH), as well as an earlier dose of eculizumab (10 days after the previous one). During admission he also required red blood cells (RBC) transfusion (3 units) and progressively recovered. 


\section{Literature Review}

Table 1 summarizes a literature review of $\mathrm{PNH}$ cases experiencing hemolytic flares after COVID-19 infection. Since March 2020, we found eight case reports describing a total of 19 patients, 15 with classic hemolytic PNH and 4 with $\mathrm{PNH}$ in the context of an aplastic anemia (9-16). Patients were mostly women $(63 \%$ females, $37 \%$ males), with a wide age range (19 to 77 years). 15 patients were on active therapy with a complement inhibitor, and four were treatment naïve. The great majority (89.4\%) experienced a mild to moderate COVID-19 infection, whilst only two subjects needed intensive care unit admission and one died of respiratory failure $(11,14)$. PNH flares had heterogenous severity with some patients requiring $\mathrm{RBC}$ transfusions and additional doses of complement inhibitors, and other experiencing only mild $\mathrm{Hb}$ reduction with slight $\mathrm{LDH}$ elevation. Importantly, no thrombotic episodes were reported. Specifically, Pike et al. reported the experience of the Leeds Paroxysmal Nocturnal Hemoglobinuria national service. Within their PNH cohort, they observed COVID-19 infection in 4 patients on anti-complement therapy (3 eculizumab, 1 ravulizumab); 75\% experienced a BTH and one patient died from respiratory failure after being intubated, despite additional doses of eculizumab for ongoing haemolysis (14). Similarly, Barcellini et al. analyzed the experience of eight Italian PNH reference centers and reported 4 patients who had positive SARS-Cov-2 on routine surveillance SARS-Cov-2 nasalpharyngeal swab. Only two subjects developed mild respiratory symptoms and only one experienced BTH. None of them required hospitalization (16). Additionally, Kulasekararaj et al. reported the clinical course, degree of intravascular hemolysis and outcomes of
COVID-19 in four PNH patients, and showed a beneficial effect of complement inhibition both in controlling the intravascular haemolysis and in dampening the hyperinflammatory lung damage due to COVID-19 (13).

Our case report along with the review of the literature suggest that PNH hemolytic flares may occur during COVID-19 infection and may be handled with transfusion support and additional doses of complement inhibitors. The latter, rather than increasing the risk of a more severe COVID-19 infection, appear to dampen the over-inflammatory state induced by SARS-CoV-2 $(16,17)$. Additionally, the role of complement activation in both early (18) and late stage (19) COVID-19 infection and the potential to target them with ravulizumab is currently being studied in two randomized controlled trials. The latter trial was interrupted early due to futility on interim analysis. The fact that no thrombotic events were observed during these acute hemolytic episodes suggest a further protective role of complement inhibition and may also be in keeping with the high level of medical surveillance/patient education in $\mathrm{PNH}$ patients.

\section{PNH Flares After SARS-CoV-2 Vaccination Case Description}

A 17-year-old man was diagnosed with classic hemolytic $\mathrm{PNH}$ in a low-income Country in 2019 and was managed with vitamin and iron support, warfarin prophylaxis, and RBC transfusions during hemolytic crises. In March 2021, he came to our center and was started on eculizumab with optimal control of intravascular hemolysis and warfarin was stopped. In July

TABLE 1 | Hemolytic flares in patients with paroxysmal nocturnal hemoglobinuria during COVID-19 infection.

\begin{tabular}{|c|c|c|c|c|c|}
\hline PNH type & Therapy & $\begin{array}{c}\mathbf{N}^{\circ} \text { of } \\
\text { patients }\end{array}$ & COVID outcome & PNH outcome & Reference \\
\hline Classic PNH & Eculizumab & 1 & Resolved & Clinical remission & $\begin{array}{l}\text { Schuller et al., Annals of } \\
\text { Hematology } 2021 \text { (9) }\end{array}$ \\
\hline Classic PNH & $\begin{array}{l}\text { LMWH, dexamethasone, cefuroxime for COVID } \\
\text { At the time of diagnosis of COVID19 the patient was } \\
\text { waiting for approval of eculizumab }\end{array}$ & 1 & $\begin{array}{l}\text { Resolved (test } \\
\text { negative after } 3 \\
\text { months) }\end{array}$ & $\begin{array}{l}\text { Clinical remissionPNH } \\
\text { clone did not change. }\end{array}$ & $\begin{array}{l}\text { Sokol et al., Case Rep Med } \\
2021 \text { (10) }\end{array}$ \\
\hline Classic PNH & $\begin{array}{l}\text { Antibiotics, Hydroxychloroquine Lopinavir/ritonavir } \\
\text { Tocilizumab for COVID } \\
\text { Eculizumab }\end{array}$ & 1 & Resolved & Clinical remission & $\begin{array}{l}\text { Genthon et al., Leukemia \& } \\
\text { Lymphoma } 2021 \text { (11) }\end{array}$ \\
\hline AA PNH & Eculizumab (2 doses) then ravulizumab (2 doses) & 1 & Resolved & $\begin{array}{l}\text { Persistence of } \\
\text { pancytopenia }\end{array}$ & $\begin{array}{l}\text { Otieno et al., Case Rep } \\
\text { Hematol } 2021 \text { (12) }\end{array}$ \\
\hline Classic PNH & $\begin{array}{l}\text { 1) Ravulizumab } \\
\text { 2) Eculizumab, blood transfusions } \\
\text { 3) naïve to complement inhibitor treatment, warfarin } \\
\text { 4) naïve to complement inhibitor treatment, warfarin }\end{array}$ & 4 & $\begin{array}{l}\text { 1)Resolved } \\
\text { 2)Resolved } \\
\text { 3)Resolved } \\
\text { 4)Resolved }\end{array}$ & $\begin{array}{l}\text { 1)Resolved } \\
\text { 2)Resolved } \\
\text { 3)Resolved } \\
\text { 4)Readmitted with } \\
\text { worsening symptoms }\end{array}$ & $\begin{array}{l}\text { Kulasekararaj et al., Br J } \\
\text { Haematol } 2020 \text { (13) }\end{array}$ \\
\hline $\begin{array}{l}\text { 1) Classic PNH } \\
\text { 2) AAPNH } \\
\text { 3) AAPNH } \\
\text { 4) AAPNH }\end{array}$ & $\begin{array}{l}\text { 1) Ravulizumab } \\
\text { 2) Eculizumab, antibiotics } \\
\text { 3) Eculizumab, } 4 \text { units packed red cells, antibiotics } \\
\text { 4) Eculizumab, } 4 \text { units packed red cells, antibiotics }\end{array}$ & 4 & $\begin{array}{l}\text { 1)Resolved } \\
\text { 2)Resolved } \\
\text { 3)Death } \\
\text { 4)Resolved }\end{array}$ & $\begin{array}{l}\text { 1) Resolved } \\
\text { 2)Resolved } \\
\text { 3) Death } \\
\text { 4)Resolved }\end{array}$ & $\begin{array}{l}\text { Pike A et al., Br J Haematol } \\
2020 \text { (14) }\end{array}$ \\
\hline Classic PNH & $\begin{array}{l}\text { 1) Eculizumab } \\
\text { 2) Eculizumab } \\
\text { 3) Eculizumab }\end{array}$ & 3 & $\begin{array}{l}\text { 1)Resolved } \\
\text { 2)Resolved } \\
\text { 3)Resolved }\end{array}$ & $\begin{array}{l}\text { 1)Resolved } \\
\text { 2)Resolved } \\
\text { 3)Resolved }\end{array}$ & $\begin{array}{l}\text { Araten et al., Am J Case } \\
\text { Reports } 2020 \text { (15) }\end{array}$ \\
\hline Classic PNH & $\begin{array}{l}\text { 1)Treatment naïve } \\
\text { 2)Ravulizumab } \\
\text { 3)Ravulizumab } \\
\text { 4)Eculizumab }\end{array}$ & 4 & $\begin{array}{l}\text { 1) Resolved } \\
\text { 2)Resolved } \\
\text { 3)Resolved } \\
\text { 4)Resolved }\end{array}$ & $\begin{array}{l}\text { 1)No BTH } \\
\text { 2)No BTH } \\
\text { 3)Resolved } \\
\text { 4)No BTH }\end{array}$ & $\begin{array}{l}\text { Barcellini W et al., Br J } \\
\text { Haematol } 2021 \text { (16) }\end{array}$ \\
\hline
\end{tabular}

PNH, paroxysmal nocturnal hemoglobinuria; AA, aplastic anemia; BTH, breakthrough hemolysis; RBC, red blood cells; rhEPO, recombinant human erythropoietin. 
2021, 5 days after the first dose of Pfizer mRNA vaccine (14 days after prior eculizumab dose), he experienced a decrease of $1.5 \mathrm{~g} / \mathrm{dL} \mathrm{Hb}$ (from 12.6 to $11.1 \mathrm{~g} / \mathrm{dL}$ ) associated with an increase in unconjugated bilirubin (1.9 to $3.2 \mathrm{mg} / \mathrm{dL}$ ) and $\mathrm{LDH}$ levels (from normal to $2 \times$ ULN). He complained of mild abdominal pain and urine darkening in the last 2 days. He received eculizumab treatment and symptoms progressively recovered soon after therapy. One-week later laboratory parameters were normalized.

\section{Literature Review}

mRNA-based vaccines act by inducing the expression of SARSCov-2 Spike protein in order to elicit immune recognition and antibody response. Yu et al. recently illustrated that Spike protein is able to activate complement alternative pathway by competing with complement factor $\mathrm{H}$ for binding heparin sulfate, thus representing a possible trigger for $\mathrm{PNH}$ reactivation (20). However, Gerber et al. recently showed that the addition of Spike protein didn't increase hemolysis of PNH erythrocytes ex vivo, suggesting that hemolysis isn't due to the direct effect of Spike protein on red blood cells but rather to the activation of the classic pathway after antibody generation (21). Clinically, $8 \mathrm{PNH}$ patients experiencing hemolytic flares after SARS-Cov-2 vaccine have been reported, including $6 \mathrm{BTH}$ and 2 exacerbations in treatment naïve subjects (Table 2) (21-23). Gerber et al. reported six patients with $\mathrm{PNH}$, who received either Moderna or PfizerBioNTech vaccine. Four, all on intravenous ravulizumab and one in combination therapy with $\mathrm{D}$ inhibitor danicopan, showed signs of BTH from the vaccine day up to 5 days later, 2 with severe anemia, and 1 requiring transfusion support. Interestingly, only 1 patient who was therapy naïve experienced a likely thrombotic episode. Five days after the second dose of the Pfizer-BioNTech vaccine, he developed abdominal pain and CT scan showed peripancreatic fat stranding indicating possible small bowel microvascular thrombosis; D-dimer was elevated, and the patient was initiated on ravulizumab with signs and symptoms recovery (21). We previously described another case of $\mathrm{PNH}$ on treatment with subcutaneous ravulizumab displaying severe BTH the day after the second dose of Moderna vaccine. She was handled with supportive treatment and recombinant erythropoietin with progressive recovery. The latter, along with that reported in the present report, were the only $2 \mathrm{BTH}$ episodes observed after SARSCoV-2 vaccine in our cohort of $13 \mathrm{PNH}$ patients on active complement inhibition who received mRNA SARS-CoV-2 vaccine from March 2021 at our center (23).

These experiences indicate that hemolytic exacerbations may occur in $\mathrm{PNH}$ patients after SARS-Cov-2 vaccine so that monitoring of blood counts and hemolytic markers in the week after vaccine doses is advisable. Patient education to recognize signs/symptoms of PNH activity is pivotal, particularly in naïve patients who may be at higher risk of developing thrombotic complications. Although Gerber et al. observed BTH episodes in patients receiving COVID-19 vaccine more than 4 weeks after last ravulizumab dose, hemolytic flares may occur as soon as the day after the last complement inhibitor administration, so that it is difficult to suggest a specific timing, although it would be advisable to give vaccinations closer to anti-complement therapy (21). Importantly, transfusion requirement was rarer after COVID-19 vaccine than during infection, and no fatalities were reported in $\mathrm{PNH}$ after vaccination, confirming that vaccine expected benefits still outweigh the risks. Additionally, the risk of complement activation after Neisseria meningitis vaccination, and leading to thrombosis in patients with PNH has been reported (24).

\section{CAD Exacerbations During COVID-19 Infection Case Description}

A 68-year-old female diagnosed with CAD in 2017 previously treated with steroids and rituximab with response, was admitted to hospital in April 2020 due to fever and shortness of breath. She complained of dark urine and jaundice during the previous 5 days. Swab and CT scan revealed SARS-CoV-2 pneumonia and laboratory tests showed severe anemia ( $\mathrm{Hb} 5.1 \mathrm{~g} / \mathrm{dL}$ ) with increased LDH 2.1 xULN. Direct antiglobulin test was confirmed positive for complement at high titer and consumption of $\mathrm{C} 3$ and $\mathrm{C} 4$ was noted (C3 $<77 \mathrm{mg} / \mathrm{dL}, \mathrm{C} 4$ undetectable). The patient was managed with oxygen support, hydroxychloroquine, antibiotics, steroids, and LMWH for COVID-19. For CAD reactivation, the patient received a total of $6 \mathrm{RBC}$ transfusions during a period of 27 days. The clinical picture progressively improved and hemolytic anemia recovered, thereby allowing steroid tapering (from $50 \mathrm{mg}$ day of prednisone reduced by $10 \mathrm{mg}$ week until $25 \mathrm{mg}$ day, then by 5 mg week until stop in about 8 weeks).

\section{Literature Review}

Available literature regarding CAD development or reactivation during COVID-19 infection is summarized in Table 3 (25-42). From March 2020, we found 20 reports of patients experiencing cold agglutinin mediated hemolysis after COVID-19 infection (11 males, 9 females, aged from 17 to 77 years). Only 2 patients had a previous history of $\operatorname{CAD}(30,42)$ whilst the others were firstly diagnosed after SARS-CoV-2 infection. All but 2 patients experienced mild to severe respiratory involvement, thereby requiring steroids, hydroxychloroquine, antibiotics, antiviral, tocilizumab, and intubation. Concerning CAD treatment, 12 patients received RBC transfusions, 8 high dose steroids, and 3 rituximab. Two patients received plasma exchange, one for CAD and one for COVID-19 itself. Four patients died despite medical interventions. One fatality occurred in a patient who experienced severe COVID-19 disease with deep venous thrombosis of upper extremities and cerebrovascular disease (33). Given the known risk of thrombosis in patients with $\mathrm{CAD}$, the authors speculated that this may have contributed to thrombosis and to the unfavorable outcome. Accordingly, other investigators have suggested that the development of autoimmune hemolysis may represent a risk factor for worse outcome in COVID-19 patients. Specifically, Algassim et al. reported that $14.7 \%$ of intensive care unit (ICU) patients with COVID-19, and $9 \%$ of non-ICU patients, had AIHA (46). These patients had significantly more severe courses with longer hospital stay as compared with anemic patients without AIHA. Although anemia and increased levels of LDH and other hemolytic markers may be nonspecifically observed during severe infections, autoimmune hemolysis should be suspected in the context of an unexplained or persistent anemia in patients with COVID-19. From a pathogenic point of view, molecular mimicry 
TABLE 2 | Hemolytic flares in patients with paroxysmal nocturnal hemoglobinuria after SARS-CoV-2 vaccine.

\begin{tabular}{|c|c|c|c|c|c|c|c|}
\hline PNH type & Therapy & $\begin{array}{c}\mathbf{N}^{\circ} \text { of } \\
\text { patients }\end{array}$ & Vaccine & Time to BTH & Therapy for BTH & Outcome & Ref. \\
\hline $\begin{array}{l}\text { 1) Classic PNH } \\
\text { 2)AA PNH } \\
\text { 3)AA } \\
\text { 4)Classic PNH } \\
\text { 5)Classic PNH } \\
\text { 6)Classic PNH }\end{array}$ & $\begin{array}{l}\text { 1)treatment naïve } \\
\text { 2)Ravulizumab } \\
\text { 3)Ravulizumab and } \\
\text { Danicopan (oral } \\
\text { complement factor D } \\
\text { inhibitor) } \\
\text { 4)Ravulizumab } \\
\text { 5)Ravulizumab } \\
\text { 6)Ravulizumab and } \\
\text { Danicopan }\end{array}$ & 6 & $\begin{array}{l}\text { 1)Pfizer } \\
\text { 2)Pfizer } \\
\text { 3)Moderna } \\
\text { 4)Moderna } \\
\text { 5)Pfizer } \\
\text { 6)Pfizer }\end{array}$ & $\begin{array}{l}\text { 1) } 5 \text { days after } \\
\text { second dose } \\
\text { 2)same day of } \\
\text { first dose } \\
\text { 3)same day of } \\
\text { second dose } \\
\text { 4)same day of } \\
\text { second dose } \\
\text { 5)No BTH } \\
\text { 6)No BTH }\end{array}$ & $\begin{array}{l}\text { 1)Ravulizumab, LMWH } \\
\text { 2)Ravulizumab } \\
\text { 3)Ravulizumab, RBC transfusion } \\
\text { 4)Ravulizumab } \\
\text { 5)Ravulizumab } \\
\text { 6)Ravulizumab }\end{array}$ & $\begin{array}{l}\text { 1) microvascular } \\
\text { bowel thrombosis } \\
\text { 2)Resolved } \\
\text { 3)Resolved } \\
\text { 4)Resolved } \\
\text { 5) resolved } \\
\text { 6) resolved }\end{array}$ & $\begin{array}{l}\text { Gerber et al., } \\
\text { Blood } 2021 \text { (21) }\end{array}$ \\
\hline Classic PNH & treatment naive & 1 & Moderna & $\begin{array}{l}\text { One day after } \\
\text { receiving the } \\
\text { second dose }\end{array}$ & $\begin{array}{l}\text { Eculizumab + methylprednisolone }+ \\
\text { RBC transfusion } \rightarrow \text { Switched to } \\
\text { Ravulizumab in the outpatient setting }\end{array}$ & Resolved & $\begin{array}{l}\text { Portuguese } \\
\text { et al., Blood } \\
\text { advances } 2021 \\
\text { (22) }\end{array}$ \\
\hline Classic PNH & Ravulizumab & 1 & Moderna & $\begin{array}{l}\text { One day after } \\
\text { receiving the } \\
\text { second dose }\end{array}$ & $\begin{array}{l}\text { Ravulizumab, antibiotics, rhEPO, } \\
\text { LMWH }\end{array}$ & Resolved & $\begin{array}{l}\text { Fattizzo B et al., } \\
\text { Am J Hematol } \\
2021 \text { (23) }\end{array}$ \\
\hline
\end{tabular}

PNH, paroxysmal nocturnal hemoglobinuria; AA, aplastic anemia; BTH, breakthrough hemolysis; RBC, red blood cells; rhEPO, recombinant human erythropoietin.

among SARS-CoV-2 antigens and red cells seem the prominent mechanism, as also described for CAD developing after Mycoplasma infection (47). Additionally, the hyperinflammation triggered by the virus itself may result in cross activation of the immune system against self-antigens in an "innocent bystander" fashion. This includes the complement cascade that may be activated through both the classic and lectin pathway. Furthermore, the oxidative stress against erythrocyte and platelet membranes typical of the septic state, may favor the exposure of phosphatidyl serine (PS) and consequent complement deposition, thus causing blood cell consumption (47-49).

Overall, the association between CAD development/ reactivation and COVID-19 infection has been reported with more than half cases showing severe anemia requiring transfusions. Interestingly, the proportion of COVID-19associated $\mathrm{CAD}$ is greater than what generally observed with CAD among all AIHAs, where CAD represent about $20 \%$ of cases (5). Most cases resolved with steroids and along with resolution of COVID-19 infection, but thrombotic episodes may occur and require prophylaxis (as also suggested for COVID-19 infection itself). Finally, it is still debated whether rituximab can be safely administered during septic state, and in most cases this treatment was deferred to allow recovery of active infection (50).

\section{CAD Exacerbations After SARS-CoV-2 Vaccination \\ Case Description}

A 59-year-old male suffering from CAD since 2019, and previously treated with rituximab, had an $\mathrm{Hb}$ drop from 10.1 to $6.8 \mathrm{~g} / \mathrm{dL}$ and $\mathrm{LDH}$ elevation $(1.8 \mathrm{xULN}) 5$ days after the second dose of Moderna vaccine. The levels of complement fractions were also decreased, with C3 $55 \mathrm{mg} / \mathrm{dL}$ (normal values $>77 \mathrm{mg} / \mathrm{dL}$ ) and undetectable C4. He had also experienced fever and pain at the injection site and complained of dark urine and jaundice starting the day after vaccination. He received steroids (1 $\mathrm{mg} / \mathrm{Kg}$ day prednisone) and recombinant erythropoietin
(40,000 UI/week of epoetin alpha subcutaneously) and $\mathrm{Hb}$ stabilized at about $8.2 \mathrm{~g} / \mathrm{dL}$. Two weeks later, rituximab was administered with progressive and complete recovery, allowing steroid tapering.

\section{Literature Review}

As shown in Table 4, only 4 cases of CAD or mixed form of AIHA (i.e., direct anti-globulin test positive for IgG plus $\mathrm{C}$ at high titer) developing $(\mathrm{N}=2)$ or reactivating $(\mathrm{N}=2)$ after SARSCoV-2 vaccination have been reported $(23,28,51,52)$. Al Aoun et al. reported a 45-year-old female patient developing severe CAD 3 days after the first dose of Pfizer vaccine. The patient was treated with blood transfusion and rituximab, achieving complete remission 8 weeks later (51). Brito et al. reported an 88-year-old woman who developed very severe AIHA (Hb $4.5 \mathrm{~g}$ / $\mathrm{dL}$ ) complicated by acute kidney injury two days after the second dose of an mRNA vaccine (not specified). The DAT revealed very high titers of anti-erythrocyte IgG autoantibodies and high antiC3d titers. The patient was treated with methylprednisolone $1 \mathrm{~g}$ boluses and was transfused with subsequent $\mathrm{Hb}$ stabilization and amelioration of hemolytic markers (52). As regards exacerbations of pre-existing CAD, Lamas et al. reported a 57year-old female who experienced shortness of breath, jaundice and mild hemoglobinuria 2 days after the first dose of an mRNA vaccine (not specified); hb had decreased to $8.6 \mathrm{~g} / \mathrm{dL}$ and the patient received prednisone $20 \mathrm{mg}$ daily with progressive improvement. The same episode occurred 2 days after the second dose of the same vaccine. Anti-Spike IgG testing showed that the patient had efficiently seroconverted (55). Interestingly, our group reported the results of a prospective monitoring of 58 individuals with AIHA, including 15 CAD during SARS-CoV-2 vaccination campaign. This consisted in testing $\mathrm{Hb}$ and $\mathrm{LDH}$ levels the week before and after each vaccine dose. We detected 3 warm AIHA and 1 CAD reactivation, all effectively managed with steroids and/or rituximab (23).

The case described and data from literature show that SARS$\mathrm{CoV}-2$ vaccination may be associated with CAD development as 
TABLE 3 | Hemolytic flares in patients with cold agglutinin disease (CAD) and warm autoimmune hemolytic anemia (WAlHA) during COVID-19 infection.

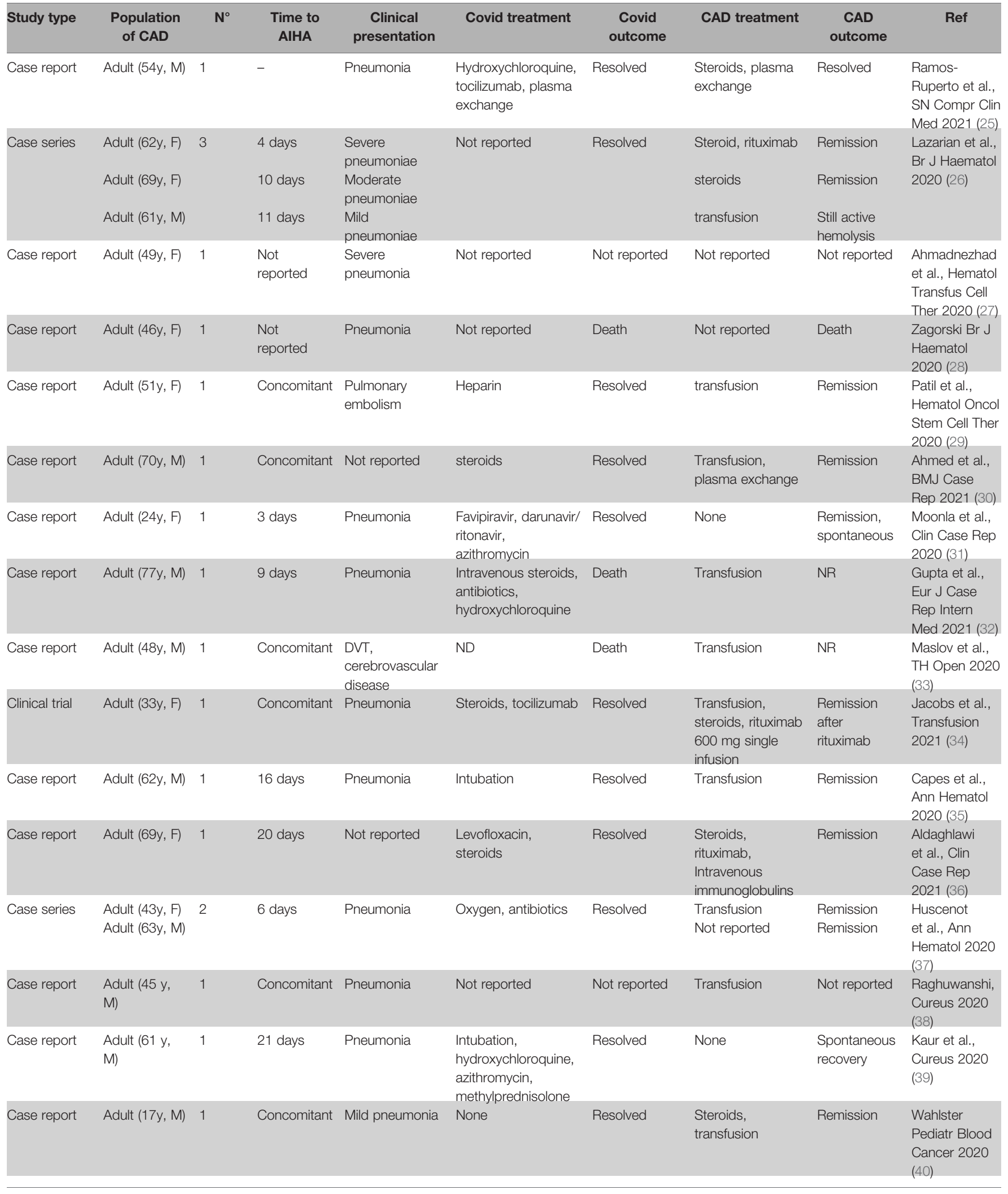


TABLE 3 | Continued

\begin{tabular}{|c|c|c|c|c|c|c|c|c|c|}
\hline Study type & $\begin{array}{c}\text { Population } \\
\text { of CAD }\end{array}$ & $\mathbf{N}^{\circ}$ & $\begin{array}{l}\text { Time to } \\
\text { AlHA }\end{array}$ & $\begin{array}{c}\text { Clinical } \\
\text { presentation }\end{array}$ & Covid treatment & $\begin{array}{l}\text { Covid } \\
\text { outcome }\end{array}$ & CAD treatment & $\begin{array}{c}\text { CAD } \\
\text { outcome }\end{array}$ & Ref \\
\hline Case report & Adult (48y, M) & 1 & 6 days & $\begin{array}{l}\text { Severe } \\
\text { pneumonia }\end{array}$ & $\begin{array}{l}\text { mechanical } \\
\text { ventilation, } \\
\text { vasopressors, } \\
\text { sedation }\end{array}$ & Resolved & Transfusion & Remission & $\begin{array}{l}\text { Hassanein } \\
\text { et al., J Med } \\
\text { Cases } 2021 \\
\text { (41) }\end{array}$ \\
\hline Cohort study & Adult $(71 y, F)$ & $\begin{array}{l}1 / 108 \\
\text { CAD } \\
\text { patients }\end{array}$ & 4 days & $\begin{array}{l}\text { Severe } \\
\text { pneumonia }\end{array}$ & $\begin{array}{l}\text { oxygen, } \\
\text { hydroxychloroquine, } \\
\text { azithromycine, } \\
\text { lopinavir/ritonavir }\end{array}$ & Resolved & $\begin{array}{l}\text { Steroids, } \\
\text { transfusions }\end{array}$ & Remission & $\begin{array}{l}\text { Barcellini et al., } \\
\text { Front Immunol } \\
2021 \text { (42) }\end{array}$ \\
\hline Study type & $\begin{array}{l}\text { Population } \\
\text { of wAlHA }\end{array}$ & $\mathbf{N}^{\circ}$ & $\begin{array}{l}\text { Time to } \\
\text { AlHA }\end{array}$ & Presentation & Covid treatment & $\begin{array}{l}\text { Covid } \\
\text { outcome }\end{array}$ & AlHA treatment & $\begin{array}{l}\text { AlHA } \\
\text { outcome }\end{array}$ & Ref \\
\hline Case report & $\begin{array}{l}\text { Adult (54y, M) } \\
\text { lgG+ }\end{array}$ & 1 & - & $\begin{array}{l}\text { Pneumonia, } \\
\text { diabetic } \\
\text { ketoacidosis, } \\
\text { acute kidney } \\
\text { injury, hematuria, } \\
\text { and anemia }\end{array}$ & - & Resolved & Steroids & Resolved & $\begin{array}{l}\text { Huda et al., } \\
\text { Cureus } 2021 \\
(43)\end{array}$ \\
\hline Case report & $\begin{array}{l}\text { Adult }(33 y, F) \\
\lg G+C_{+}\end{array}$ & 1 & - & Asymoptomatic & - & . & $\begin{array}{l}\text { Transfusions, } \\
\text { Steroids }\end{array}$ & Resolved & $\begin{array}{l}\text { Liput et al., } \\
\text { Cureus } 2021 \\
(44)\end{array}$ \\
\hline Case series & $\begin{array}{l}\text { Adult }(72 y, F) \\
\operatorname{lgG}+ \\
\text { Adult }(76 y, F) \\
\text { lgG+ }\end{array}$ & $2 / 3$ & concomitant & $\begin{array}{l}\text { Bilateral } \\
\text { pneumonia in } \\
\text { both }\end{array}$ & $\begin{array}{l}\text { Hydroxychloroquine, } \\
\text { dexamethasone and } \\
\text { tocilizumab }\end{array}$ & Resolved & $\begin{array}{l}\text { Transfusion, } \\
\text { steroids }\end{array}$ & Resolved & $\begin{array}{l}\text { Ramos- } \\
\text { Ruperto et al., } \\
\text { SN Compr Clin } \\
\text { Med } 2021 \text { (25) }\end{array}$ \\
\hline Case series & $\begin{array}{l}\text { Adult }(61 y, M) \\
\text { lgG+C+ } \\
\text { Adult }(89 y, F) \\
\text { lgG+ } \\
\text { Adult }(61 y, M) \\
\text { lgG+ } \\
\text { Adult }(75 y, M) \\
\text { lgG+ }\end{array}$ & $4 / 6$ & $\begin{array}{l}13 \text { days } \\
7 \text { days } \\
9 \text { days } \\
6 \text { days }\end{array}$ & $\begin{array}{l}\text { Moderate } \\
\text { pneumonia } \\
\text { Mild pneumonia } \\
\text { Severe } \\
\text { pneumonia } \\
\text { Moderate } \\
\text { pneumonia }\end{array}$ & $\begin{array}{l}\text { Oxygen, Steroids, } \\
\text { hydroxychloroquine, } \\
\text { lopinavir and } \\
\text { ritonavir. }\end{array}$ & Resolved & $\begin{array}{l}\text { Steroids and } \\
\text { transfusions, } \\
\text { rituximab in } 1\end{array}$ & $\begin{array}{l}\text { Not resolved } \\
\text { at the time of } \\
\text { publication }\end{array}$ & $\begin{array}{l}\text { Lazarian et al., } \\
\text { Br J Haematol } \\
2020 \text { (26) }\end{array}$ \\
\hline Case report & $\begin{array}{l}\text { Adult }(24 y, M) \\
\text { lgG+C AlHA }\end{array}$ & 1 & concomitant & $\begin{array}{l}\text { Fever, myalgias } \\
\text { and cough, } \\
\text { pulmonary } \\
\text { embolism, } \\
\text { encephalitis }\end{array}$ & $\begin{array}{l}\text { Steroids, } \\
\text { anticoagulants, } \\
\text { intubation, } \\
\text { vasopressors, } \\
\text { intravenous } \\
\text { immunoglobulin }\end{array}$ & $\begin{array}{l}\text { Superimposed } \\
\text { Cryptococcus } \\
\text { neoformans } \\
\text { infection and } \\
\text { death }\end{array}$ & $\begin{array}{l}\text { Steroids, } \\
\text { cyclophosphamide }\end{array}$ & $\begin{array}{l}\text { Partial } \\
\text { remission }\end{array}$ & $\begin{array}{l}\text { Woldie et al., J } \\
\text { Med Cases } \\
2020 \text { (45) }\end{array}$ \\
\hline \multirow[t]{2}{*}{$\begin{array}{l}\text { Retrospective } \\
\text { study }\end{array}$} & $\begin{array}{l}\text { Adult }(59 y, M) \\
\operatorname{lgG}+\end{array}$ & 2/139 & - & $\begin{array}{l}\text { Bilateral } \\
\text { pneumonia and } \\
\text { dysimmune } \\
\text { encephalitis }\end{array}$ & $\begin{array}{l}\text { intubation, steroids, } \\
\text { hydroxychloroquine, } \\
\text { tocilizumab, } \\
\text { darunavir, and LMWH } \\
\text { prophylaxis, Ivlg }\end{array}$ & Resolved & Nothing & Remission & $\begin{array}{l}\text { Barcellini et al., } \\
\text { Front Immunol } \\
2020 \text { (42) }\end{array}$ \\
\hline & $\begin{array}{l}\text { Adult }(78 y, M) \\
\operatorname{lgG}+\end{array}$ & & 3 weeks & $\begin{array}{l}\text { moderate } \\
\text { pneumonia }\end{array}$ & $\begin{array}{l}\text { oxygen support, } \\
\text { steroids, HCQ, } \\
\text { azithromycine, full- } \\
\text { dose LMWH }\end{array}$ & & Steroids and IVIG & & \\
\hline Case report & $\begin{array}{l}\text { Adult }(33 y, F) \\
\lg G+C_{+}\end{array}$ & 1 & concomitant & $\begin{array}{l}\text { Bilateral } \\
\text { pneumonia }\end{array}$ & Steroids, tocilizumab & Resolved & $\begin{array}{l}\text { Trasnfusion, } \\
\text { steroids, rituximab }\end{array}$ & Remisson & $\begin{array}{l}\text { Jacobs et al., } \\
\text { Transfusion } \\
2021 \text { (34) }\end{array}$ \\
\hline
\end{tabular}

well as with exacerbation in less than $10 \%$ of pre-existing CAD cases (i.e., 1/15 in our experience). CAD exacerbations are unpredictable, may occur after either after the first or the second dose, and regardless of vaccine type. Since most cases may be successfully managed with steroids and transfusion, prospective hematologic monitoring as adopted in our survey (1 week before, 1 week after the first and the second dose) appears appropriate to intercept and manage hemolytic flares. Similarly to what described for PNH, CAD episodes following COVID-19 vaccine are milder than those following infection, with no thrombotic nor fatal events, strengthening the message that the benefits of vaccination greatly outweigh the risks.

\section{Exacerbations/Development of wAIHA After COVID-19 Infection or SARS-CoV-2 Vaccination}

Eleven patients with warm type AIHA developing or reactivating during COVID-19 infection have been reported in the literature (Table 3) (25, 26, 34, 42, 44, 45, 54). Of these patients, 4 showed complement positivity at DAT evaluation $(26,34,44,45)$. 
TABLE 4 | Hemolytic flares in patients with cold agglutinin disease (CAD) and warm autoimmune hemolytic anemia (wAlHA) after SARS-CoV-2 vaccine.

\begin{tabular}{|c|c|c|c|c|c|c|c|}
\hline $\begin{array}{l}\text { Study } \\
\text { type }\end{array}$ & Population & $\mathbf{N}^{\circ}$ & Vaccine & $\begin{array}{l}\text { Time to } \\
\text { event }\end{array}$ & AlHA treatment & $\begin{array}{c}\text { AlHA } \\
\text { outcome }\end{array}$ & Ref \\
\hline $\begin{array}{l}\text { Case } \\
\text { report }\end{array}$ & Adult (45y, F) CAD & 1 & Pfizer, $1^{\text {st }}$ dose & 4 days & blood transfusions, rituximab & Remission & $\begin{array}{l}\text { Al Aoun and } \\
\text { Motabi (51) }\end{array}$ \\
\hline $\begin{array}{l}\text { Case } \\
\text { report }\end{array}$ & Adult (88y, F) CAD & 1 & $\begin{array}{l}\text { mRNA vaccine, } \\
2^{\text {nd }} \text { dose }\end{array}$ & 2 days & Transfusions, methylprednisolone $1 \mathrm{~g}$ bolus & Remission & Brito et al. (52) \\
\hline $\begin{array}{l}\text { Case } \\
\text { report }\end{array}$ & Adult $(57 y, F)$ CAD & 1 & $\begin{array}{l}\text { mRNA vaccine, } \\
1^{\text {st }} \text { dose } \\
\text { mRNA vaccine, } \\
2^{\text {nd }} \text { dose }\end{array}$ & $\begin{array}{l}2 \text { days } \\
5 \text { days }\end{array}$ & prednisone 20 mg day & Remission & Zagorski et al. (28) \\
\hline $\begin{array}{l}\text { Cohort } \\
\text { study }\end{array}$ & Adult $(77 y, M)$ CAD & $\begin{array}{l}1 / 15 \mathrm{CAD} \\
\text { patients }\end{array}$ & $\begin{array}{l}\text { Moderna vaccine, } \\
1^{\text {st }} \text { dose }\end{array}$ & 7 days & Steroids, rituximab, recombinant erythropoietin & Remission & Fattizzo et al. (53) \\
\hline \multirow[t]{3}{*}{$\begin{array}{l}\text { Cohort } \\
\text { study }\end{array}$} & $\begin{array}{l}\text { Adult }(79 y, F) \lg G \\
+\lg A+\text { wAlHA }\end{array}$ & $\begin{array}{l}\text { 3/41 wAlHA } \\
\text { patients }\end{array}$ & $\begin{array}{l}\text { Pfizer vaccine, } 1^{\text {st }} \\
\text { dose }\end{array}$ & 7 days & Steroids & Remission & Fattizzo et al. (53) \\
\hline & $\begin{array}{l}\text { Adult }(73 y, M) \lg G+ \\
\text { WAlHA }\end{array}$ & & $\begin{array}{l}\text { Moderna vaccine, } \\
1^{\text {st }} \text { dose }\end{array}$ & 7 days & Steroids & & \\
\hline & $\begin{array}{l}\text { Adult }(73 y, M) \operatorname{lgG} \\
+ \text { wAlHA }\end{array}$ & & $\begin{array}{l}\text { Pfizer vaccine, } \\
2^{\text {nd }} \text { dose }\end{array}$ & 5 days & Steroids & & \\
\hline $\begin{array}{l}\text { Case } \\
\text { report }\end{array}$ & $\begin{array}{l}\text { Adult (41 y, F) lgG+ } \\
\text { WAlHA }\end{array}$ & 1 & $\begin{array}{l}\text { Moderna, } 1^{\text {st }} \\
\text { dose }\end{array}$ & 20 days & $\begin{array}{l}\text { Transfusion, steroids, rituximab, mycophenolate } \\
\text { mofetil, and immunoglobulins }\end{array}$ & Remission & Gadi et al. (54) \\
\hline $\begin{array}{l}\text { Case } \\
\text { report }\end{array}$ & $\begin{array}{l}\text { Adult }(88 y, F) \lg G+C \\
+ \text { WAlHA }\end{array}$ & 1 & $\begin{array}{l}\text { mRNA vaccine, } \\
2^{\text {nd }} \text { dose }\end{array}$ & 2 days & Transfusions, steroids & Remission & $\begin{array}{l}\text { Brito et al., Cureus } \\
2021 \text { (52) }\end{array}$ \\
\hline
\end{tabular}

WAIHA flares occurred concomitantly with- or up to 21 days after initial COVID-19 detection and were mostly managed with transfusions and steroids. Only 2 patients required rituximab and 1 received cyclophosphamide. Notably, we previously reported 2 patients out of a cohort of 139 wAIHA patients who experienced a severe COVID-19 infection (42). Only one experienced wAIHA reactivation 3 weeks after COVID-19 pneumonia and was effectively managed with steroids and intravenous immunoglobulins. Additionally, 5 cases of wAIHA (only 1 had DAT positive for IgG and C3d) developing or reactivating after mRNA SARS-CoV-2 vaccination have been described, 3 after the $1^{\text {st }}$ and 2 after the $2^{\text {nd }}$ dose (Table 4) $(23,52$, 54). Three cases had a severe presentation (i.e., $\mathrm{Hb}<8 \mathrm{~g} / \mathrm{dL}$ ), 2 required transfusions and only one subject received therapy other than steroids (rituximab and mycophenolate). Overall, as outlined for patients with CAD, hemolytic flares after COVID-19 infection appear more severe than those occurring after vaccination and the same monitoring of blood counts and LDH should be applied.

\section{Exacerbations/Development of HUS During COVID-19 Infection}

The review of the literature showed a total of 9 patients with HUS associated with COVID-19 infection (Table 5) (56-59). Eight subjects developed an atypical HUS and 1 a typical HUS with bloody diarrhea in the preceding days and confirmed E. coli infection. Interestingly, most patients had mild or asymptomatic COVID-19 infection, whilst HUS presented with severe haemolytic anemia and acute kidney injury requiring transfusions, hemodialysis, and the $\mathrm{C} 5$ inhibitor eculizumab in 7 cases (56-59). All HUS flares occurred within 1 month from COVID-19 infection, mostly concomitantly, and all resolved. The largest cohort was that reported by El Sissy et al., who noted a sharp contrast between mild respiratory symptoms and severe renal and neurological HUS manifestations (54). Importantly, 3/5 subjects had undergone a previous renal transplant and were receiving tacrolimus/everolimus therapy that may have contributed to trigger HUS. Interestingly, patients with COVID-19- associated atypical HUS, who underwent genetic testing, were found to harbour genetic complement dysregulation, and 2 patients were positive for antibodies against complement factor $\mathrm{H}$. Although limited, available data suggest that COVID-19 is a potential trigger for HUS, in accordance with previous data on complement-mediated aHUS precipitated by viral infections such as Influenza. The clinical suspicion should be acute to prompt quick diagnosis and establishment of supportive treatment (hemodialysis, transfusions and plasma exchange), along with use of anti-complement therapies.

\section{Discussion and Conclusions}

There is an association between COVID-19 and exacerbations of complement mediated hemolytic anemias. Although hemolytic flares in these diseases may be observed upon several infectious triggers (i.e., Mycoplasma pneumoniae, hepatitis, herpetic viruses, human immunodeficiency virus, Influenza virus, etc) $(4,60)$, and sporadically after other vaccines (i.e., Influenza vaccine) (61-63), SARS-CoV-2 seems to induce a higher and broader complement activation. Complement is clearly involved in the pathogenesis of COVID-19, namely respiratory failure, intravascular coagulopathy, and over-inflammation. Recently, it has been shown that a prominent activation of the alternative and lectin complement pathways identify a subset of severe COVID-19 patients with a higher proportion of fatalities, need of oxygen support, and ICU admission (64-67). If during COVID-19 infection alternative and lectin pathways are more involved, SARS-CoV-2 vaccine seems to mainly act through the classical pathway activation (21). As a matter of fact, complement activation has a dichotomous nature since it does contribute to the hyper-inflammatory state but may also exert a neutralizing effect against SARS-CoV-2 infection. This may account for the controversial results of ongoing trials with complement inhibitors $(18,19,68-70)$. Likewise, immunosuppressive treatment in 
TABLE 5 | Hemolytic flares in patients with hemolytic uremic syndrome (HUS) during COVID-19 infection.

\begin{tabular}{|c|c|c|c|c|c|c|c|c|c|}
\hline $\begin{array}{l}\text { Study } \\
\text { type }\end{array}$ & Population & $\mathbf{N}^{\circ}$ & $\begin{array}{l}\text { Time to } \\
\text { AlHA }\end{array}$ & Clinical presentation & $\begin{array}{l}\text { Covid } \\
\text { treatment }\end{array}$ & $\begin{array}{l}\text { Covid } \\
\text { outcome }\end{array}$ & Hemolytic treatment & $\begin{array}{l}\text { hemolytic } \\
\text { outcome }\end{array}$ & Ref \\
\hline $\begin{array}{l}\text { Case } \\
\text { series }\end{array}$ & $\begin{array}{l}5 \text { patients } \\
\text { with COVID- } \\
19- \\
\text { associated } \\
\text { atypical } \\
\text { HUS }\end{array}$ & 5 & $\begin{array}{l}\text { Concomitant } \\
\text { to } 30 \text { days }\end{array}$ & $\begin{array}{l}\text { mild respiratory symptoms renal ysfunction, } \\
\text { severe thrombocytopenia, neurological } \\
\text { symptoms (confusion, central facial palsy), } \\
\text { intestinal involvement (pain, diarrhoea), intestinal } \\
\text { capillary thrombi. }\end{array}$ & $\begin{array}{l}\text { Oxygen in } \\
1 / 5 \\
\text { patients }\end{array}$ & Resolved & $\begin{array}{l}\text { Two patients } \\
\text { underwent plasma } \\
\text { exchanges with fresh } \\
\text { frozen plasma, while } \\
\text { three were } \\
\text { treated with } \\
\text { eculizumab. Patient } 4 \\
\text { received two infusions } \\
\text { of rituximab for anti-FH } \\
\text { antibodies. }\end{array}$ & All resolved & $\begin{array}{l}\text { El Sissy } \\
\text { et al., } \\
\text { Blood } \\
2021(56)\end{array}$ \\
\hline $\begin{array}{l}\text { Case } \\
\text { series }\end{array}$ & $\begin{array}{l}\text { Adult }(22 y, F) \\
\text { atypical } \\
\text { HUS } \\
\text { Adult }(52 y, F) \\
\text { atypical } \\
\text { HUS }\end{array}$ & 2 & $\begin{array}{l}\text { Concomitant } \\
2 \text { days }\end{array}$ & $\begin{array}{l}\text { Diarrhea, vomiting, loss of taste, fatigue, severe } \\
\text { hemolytic anemia } \\
\text { flu-like symptoms, loss of taset, fatigue, } \\
\text { abdominal cramps, severe hemolysis }\end{array}$ & - & - & $\begin{array}{l}\text { Hemodialysis, } \\
\text { Transfusions, plasma } \\
\text { exchange, eculizumab } \\
\text { Ttransfusions, } \\
\text { hemodialysis, } \\
\text { eculizumab }\end{array}$ & $\begin{array}{l}\text { Both cases } \\
\text { Resolved }\end{array}$ & $\begin{array}{l}\text { Kaufeld } \\
\text { et al., } \\
\text { Kidney Int } \\
\text { Rep } 2021 \\
\text { (57) }\end{array}$ \\
\hline $\begin{array}{l}\text { Case } \\
\text { report }\end{array}$ & $\begin{array}{l}\text { Adult }(28 y, F) \\
\text { atypical } \\
\text { HUS }\end{array}$ & 1 & Concomitant & $\begin{array}{l}\text { Fever, dysphagia, headache, hemolytic anemia, } \\
\text { mild thrombocytopenia, acute kidney injury }\end{array}$ & - & - & $\begin{array}{l}\text { Eculizumab, penicillin } \\
\text { prophylaxis, } \\
\text { anticoagulation }\end{array}$ & Resolved & $\begin{array}{l}\text { Ville et al., } \\
\text { Kidney Int } \\
2021 \text { (58) }\end{array}$ \\
\hline $\begin{array}{l}\text { Case } \\
\text { report }\end{array}$ & $\begin{array}{l}\text { Adult }(24 y, F) \\
\text { typical HUS }\end{array}$ & 1 & Concomitant & $\begin{array}{l}\text { bloody diarrhea, acute kidney injury, and focal } \\
\text { seizures }\end{array}$ & - & - & $\begin{array}{l}\text { Eculizumab, } \\
\text { lorazepam, } \\
\text { levetiracetam, valproic } \\
\text { acid }\end{array}$ & Resolved & $\begin{array}{l}\text { Simpson } \\
\text { et al., } \\
\text { Epilepsy } \\
\text { Behav Rep } \\
2021 \text { (59) }\end{array}$ \\
\hline
\end{tabular}

immune-mediated anemias may have a dual effect in reducing hyperinflammation and dampening immunocompetence.

Patient education is pivotal to promptly recognize signs/ symptoms of hemolytic flares and to seek medical attention. The latter should be always high and should focus on the assessment of the severity of hemolytic exacerbation to prompt treatment choice (transfusions, complement inhibitor initiation/additional dose in the case of $\mathrm{PNH}$, steroids/rituximab in the case of CAD and wAIHA, plasma exchange, hemodialysis and complement inhibitor in the case of aHUS) and anti-thrombotic prophylaxis. Since most episodes occurred within the first 10 days after COVID-19 infection/ vaccination, laboratory monitoring in that period appears feasible and cost-effective. Finally, hemolytic exacerbations occurring during COVID-19 infection were more severe, required higher therapeutic burden, and carried more complications including fatalities, as compared to those developing after SARS-CoV-2 vaccine. This highlights the importance of vaccinating this patient population but with meticulous monitoring for complications.

\section{REFERENCES}

1. Ma L, Sahu SK, Cano M, Kuppuswamy V, Bajwa J, McPhatter J, et al. Increased Complement Activation Is a Distinctive Feature of Severe SARSCoV-2 Infection. Sci Immunol (2021) 6:1-18. doi: 10.1126/sciimmunol. abh2259

2. Gao T, Hu M, Zhang X, Li H, Zhu L, Dong Q, et al. Highly Pathogenic Coronavirus N Protein Aggravates Lung Injury by MASP-2-Mediated Complement Over-Activation. medRxiv. doi: 10.1101/2020.03.29.20041962

3. Fodil S, Annane D. Complement Inhibition and COVID-19: The Story So Far. Immunotargets Ther (2021) 10:273-84. doi: 10.2147/ITT.S284830

4. Brodsky RA. How I Treat Paroxysmal Nocturnal Hemoglobinuria. Blood (2021) 137(10):1304-9. doi: 10.1182/blood.2019003812

\section{DATA AVAILABILITY STATEMENT}

The raw data supporting the conclusions of this article will be made available by the authors, without undue reservation.

\section{ETHICS STATEMENT}

The studies involving human participants were reviewed and approved by Comitato Etico Milano Area 2. The patients/ participants provided their written informed consent to participate in this study.

\section{AUTHOR CONTRIBUTIONS}

All authors equally contributed to the present article.

5. Berentsen S. New Insights in the Pathogenesis and Therapy of Cold AgglutininMediated Autoimmune Hemolytic Anemia. Front Immunol (2020) 11:590.eCollection 2020. doi: 10.3389/fimmu.2020.00590.eCollection2020

6. Röth A, Barcellini W, D'Sa S, Miyakawa Y, Broome CM, Michel M, et al. Sutimlimab in Cold Agglutinin Disease. N Engl J Med (2021) 384(14):132334. doi: 10.1056/NEJMoa2027760

7. Barcellini W, Zaninoni A, Giannotta JA, Fattizzo B. New Insights in Autoimmune Hemolytic Anemia: From Pathogenesis to Therapy. J Clin Med (2020) 9:3859. doi: 10.3390/jcm9123859

8. Jokiranta TS. HUS and Atypical HUS. Blood (2017) 129(21):2847-56. doi: 10.1182/blood-2016-11-709865

9. Schüller H, Klein F, Lübbert M, Prager EP. Hemolytic Crisis in a Patient Treated With Eculizumab for Paroxysmal Nocturnal Hemoglobinuria 
Possibly Triggered by SARS-CoV-2 (COVID-19): A Case Report. Ann Hematol (2021) r100(3):841-2. doi: 10.1007/s00277-020-04318-6

10. Sokol J, Nehaj F, Mokan M, Lisa L, Stasko J. COVID19 Infection in a Patient With Paroxysmal Nocturnal Hemoglobinuria: A Case Report. Case Rep Med (Baltimore) (2021) 100(20):e25456. doi: 10.1097/MD.0000000000025456

11. Genthon A, Chiarabini T, Baylac P, Valin N, Ubrina T, Pakanowski J, et al. Severe COVID-19 Infection in a Patient With Paroxysmal Nocturnal Hemoglobinuria on Eculizumab Therapy. Leuk Lymphoma (2021) 62 (6):1502-5. doi: 10.1080/10428194.2020.1869963

12. Otieno SB, Altahan A, Kaweeta F, Karri S, Alnoor F, Johnson R. Severe Hemolysis in a COVID-19 Patient With Paroxysmal Nocturnal Hemoglobinuria. Case Rep Hematol (2021) 2021:6619177. doi: 10.1155/2021/6619177

13. Kulasekararaj AG, Lazana I, Large J, Posadas K, Eagleton H, Lord Villajim J, et al. Terminal Complement Inhibition Dampens the Inflammation During COVID-19. Br J Haematol (2020) 190(3):e141-3. doi: 10.1111/bjh.16916

14. Pike A, Muus P, Munir T, Mitchell L, Arnold L, Riley K, et al. Griffin M COVID-19 Infection in Patients on Anti-Complement Therapy: The Leeds National Paroxysmal Nocturnal Hemoglobinuria Service Experience. $\mathrm{Br} J$ Haematol (2020) 191(1):e1-4. doi: 10.1111/bjh.17097

15. Araten DJ, Belmont HM, Schaefer-Cutillo J, Iyengar A, Mattoo A. Reddy R Mild Clinical Course of COVID-19 in 3 Patients Receiving Therapeutic Monoclonal Antibodies Targeting C5 Complement for Hematologic Disorders. Am J Case Rep (2020) 21:e927418. doi: 10.12659/AJCR.927418

16. Barcellini W, Fattizzo B, Quattrocchi L, Giannotta JA, Aydin S, Barone F, et al. Covid-19 Infection in Patients With PNH: An Italian Multicenter Survey. $\mathrm{Br} J$ Haematol (2021) 194(5):854-6. doi: 10.1111/bjh.17558

17. Risitano AM, Mastellos DC, Huber-Lang M, Yancopoulou D, Garlanda C, Ciceri F, et al. Complement as a Target in COVID-19? Nat Rev Immunol (2020) 20(6):343-4. doi: 10.1038/s41577-020-0320-7

18. Kulkarni S, Fisk M, Kostapanos M, Banham-Hall E, Bond S, Hernan-Sancho E, et al. Repurposed Immunomodulatory Drugs for Covid-19 in Pre-ICu Patients - mulTi-Arm Therapeutic Study in Pre-ICu Patients Admitted With Covid-19 - Repurposed Drugs (TACTIC-R): A Structured Summary of a Study Protocol for a Randomised Controlled Trial. Trials (2020) 21(1):626. doi: 10.1186/s13063-020-04535-4

19. Efficacy and Safety Study of IV Ravulizumab in Patients With COVID-19 Severe Pneumonia. Available at: https://clinicaltrials.gov/ct2/show/ NCT04369469 (Accessed 6th October 2021).

20. Yu J, Yuan X, Cjhen H, Chaturvedi S, Braunstein EM. Brodsky RA Direct Activation of the Alternative Complement Pathway by SARS-CoV-2 Spike Proteins Is Blocked by Factor D Inhibition. Blood (2020) 136(18):2080-9. doi: 10.1182/blood.2020008248

21. Gerber GF, Yuan X YUJ, Cher BAY, Braunstein EM, Chaturvedi S, Brodsky RA. COVID-19 Vaccines Induce Severe Hemolysis in Paroxysmal Nocturnal Hemoglobinuria. Blood (2021) 137(26):3670-3. doi: 10.1182/blood. 2021011548

22. Portuguese AJ, Sunga C, Kruse-Jarres R, Gernsheimer T, Abkowitz JN. Autoimmune- and Complement-Mediated Hematologic Condition Recrudescence Following Sars-Cov-2 Vaccination. Blood Adv (2021) 5 (13):2794-8. doi: 10.1182/bloodadvances.2021004957

23. Fattizzo B, Giannotta JA, Cecchi N, Barcellini W. Sars-CoV2-Vaccination Induces Breakthrough Hemolysis in PNH on Complement Inhibitor. Am J Hematol (2021) 96(9):E344-6. doi: 10.1002/ajh.26262

24. Arnold L, Kelly R, Munir T, Muus P, Pike A, Riley K, et al. 1684 Thrombotic Events With Neisseria Meningitidis Vaccination in Patients With Paroxysmal Nocturnal Hemoglobinuria, UK Experience. Blood (2020) 136(suppl 1):35-6. doi: 10.1182/blood-2020-141769

25. Ramos Ruperto L, Garcìa Pérez R, Hernández-Maraver D, Kerguelén-Fuentes A, Viejo-Llorente A, Robles-Marhuenda Á, et al. A 3-Case Series of Autoimmune Haemolytic Anaemia and COVID-19: Is Plasma Exchange an Alternative? SN Compr Clin Med (2021) 3:1420-3. doi: 10.1007/s42399-021-00884-6

26. Lazarian G, Quinquenel A, Bellal M, Siavellis J, Jacquy C, Re D, et al. Autoimmune Haemolytic Anaemia Associated With COVID-19 Infection. Br J Haematol (2020) 190(1):29-31. doi: 10.1111/bjh.16794

27. Ahmadnezhad M, Mosleh M, Ferdowsi S, Mohammadi S, Eshghi P, Oodi A. Cold Agglutinin Associated With COVID-19 Infection in a Thalassemia Patient With Multiple Alloantibodies: A Case of Cold Hemagglutinin
Disease (CAD) With Complex Antibody Detection. Hematol Transfus Cell Ther (2021) 43(3):361-3. doi: 10.1016/j.htct.2021.04.005

28. Zagorski E, Pawar T, Rahimian S, Forman D. Cold Agglutinin Autoimmune Haemolytic Anaemia Associated With Novel Coronavirus (COVID-19). Br J Haematol (2020) 190(4):e183-4. doi: 10.1111/bjh.16892

29. Patil NH, Herc ES, Girgis M. Cold Agglutinin Disease and Autoimmune Hemolytic Anemia With Pulmonary Embolism as a Presentation of COVID19 Infection. Hematol Oncol Stem Cell Ther (2020) S1658-3876(20)30116-3. doi: 10.1016/j.hemonc.2020.06.005

30. Ahmed Y, Khandelwal A, Walker L. Cold Agglutinin Disease and COVID-19 Requiring Therapeutic Plasma Exchange. Case Rep (2021) 14(7):e244227. doi: 10.1136/bcr-2021-244227

31. Moonla C, Suwanpimolkul G, Paitoonpong L, Jantarabenjaku W, Chanswangphuwana C, Polprasert C, et al. Cold Agglutinin Disease Following SARS-CoV-2 and Mycoplasma Pneumoniae Co-Infections. Clin Case Rep (2020) 8(12):2402-5. doi: 10.1002/ccr3.3152

32. Gupta R, Singh S, Anusim N, Gupta S, Gupta S, Huben M, et al. Coronavirus Disease 2019 and Cold Agglutinin Syndrome: An Interesting Case. Case Rep Intern Med (2021) 8(3):2387. doi: 10.12890/2021_002387.eCollection2021

33. Maslov DV, Simenson V, Jain S, Badari A. COVID-19 and Cold Agglutinin Hemolytic Anemia. TH Open (2020) 4(3):e175-7. doi: 10.1055/s-00401715791.eCollection2020Jul

34. Jacobs J, Eichbaum Q. COVID-19 Associated With Severe Autoimmune Hemolytic Anemia. Transfusion (2021) 61(2):635-40. doi: 10.1111/trf.16226

35. Capes A, Bailly S, Hantson P, Gerard L, Laterre PF. COVID-19 Infection Associated With Autoimmune Hemolytic Anemia. Ann Hematol (2020) 99 (7):1679-80. doi: 10.1007/s00277-020-04137-9

36. Aldaghlawi F, Shammah A, Kio E. SARS-CoV-2 Infection Complicated With Cold Agglutinin Disease and Myositis. Clin Case Rep (2021) 9(4):2196-9. doi: 10.1002/ccr3.3981.eCollection2021Apr

37. Huscenot T, Galland J, Ouvrat M, Rossignol M, Mouly S, Sène D, et al. SARSCoV-2-Associated Cold Agglutinin Disease: A Report of Two Cases. Ann Hematol (2020) 99(8):1943-4. doi: 10.1007/s00277-020-04129-9

38. Raghuwanshi B. Serological Blood Group Discrepancy and Cold Agglutinin Autoimmune Hemolytic Anemia Associated With Novel Coronavirus Cureus. Cureus (2020) 12(11):e11495. doi: 10.7759/cureus.11495

39. Kaur J, Mogulla S, Khan R, Krishnamoorthy G, Garg S. Transient Cold Agglutinins in a Patient With COVID-19. Cureus (2021) 13(1):e12751. doi: $10.7759 /$ cureus. 12751

40. Wahlster L, Weichert-Leahey N, Trissal M, Grace RF. Sankaran VG.COVID19 Presenting With Autoimmune Hemolytic Anemia in the Setting of Underlying Immune Dysregulation. Pediatr Blood Cancer (2020) 67(9): e28382. doi: $10.1002 /$ pbc. 28382

41. Hassanein H, Hajdenberg J. High Thermal Amplitude Red Blood Cell Agglutinating Cold Type Autoantibodies in a Case of Severe Acute Respiratory Syndrome Coronavirus 2 Pneumonia and Multiorgan Failure. J Med Cases (2021) 12(1):16-7. doi: 10.14740/jmc3608

42. Barcellini W, Giannotta JA, Fattizzo B. Are Patients With Autoimmune Cytopenias at Higher Risk of COVID-19 Pneumonia? The Experience of a Reference Center in Northern Italy and Review of the Literature. Front Immunol (2021). doi: 10.3389/fimmu.2020.609198

43. Huda Z, Jahangir A, Sahra S, Rafay Khan Niazi M, Anwar S, Glaser A, et al. A Case of COVID-19-Associated Autoimmune Hemolytic Anemia With Hyperferritinemia in an Immunocompetent Host. Cureus (2021) 13(6): e16078. doi: $10.7759 /$ cureus. 16078

44. Liput JR, Jordan K, Patadia R, Kander E. Warm Autoimmune Hemolytic Anemia Associated With Asymptomatic SARS-CoV-2. Infect Cureus (2021) 13(3):e14101. doi: 10.7759/cureus.14101

45. Woldie IL, Brown IG, Nwadiaro NF, Patel A, Jarrar M, Quint E, et al. Med Cases. J Med Cases (2020) 11(11):362-5. doi: 10.14740/jmc3575

46. Algassim AA, Elghazaly AA, Alnahdi AS, Mohammed-Rahim OM, Alanazi AG, Aldhuwayhi NA, et al. Prognostic Significance of Hemoglobin Level and Autoimmune Hemolytic Anemia in SARS-CoV-2 Infection. Ann Hematol (2021) 100(1):37-43. doi: 10.1007/s00277-020-04256-3

47. Angileri F, Legare S, Marino Gammazza A, Conway de Macario E, Jl Macario A, Cappello F. Molecular Mimicry may Explain Multi-Organ Damage in COVID19. Autoimmun Rev (2020) 19(8):102591. doi: 10.1016/j.autrev.2020.102591 
48. Chauhan N, Jaggi M, Chauhan SC, Yallapu MM. COVID-19: Fighting the Invisible Enemy With microRNAs. Expert Rev Anti Infect Ther (2021) 19 (2):137-45. doi: 10.1080/14787210.2020.1812385

49. Kubánková M, Hohberger B, Hoffmanns J, Fürst J, Herrmann M, Guck J, et al. Physical Phenotype of Blood Cells Is Altered in COVID-19. Biophys J (2021) 120(14):2838-47. doi: 10.1016/j.bpj.2021.05.025

50. Fattizzo B. Evans Syndrome and Infections: A Dangerous Cocktail to Manage With Caution. Blood Transfus (2021) 19(1):5-8. doi: 10.2450/2021.0351-20

51. Al Aoun S, Motabi I. Cold Agglutinin Disease After COVID-19 Vaccine. $\mathrm{Br} J$ Haematol (2021). doi: 10.1111/bjh.17674

52. Brito S, Ferreira N, Mateus S, Bernardo M, Pinto B, Lourenço A, et al. A Case of Autoimmune Hemolytic Anemia Following COVID-19 Messenger Ribonucleic Acid Vaccination. Cureus (2021) 13(5):e15035. doi: 10.7759/ cureus. 15035

53. Fattizzo B, Giannotta JA, Cecchi N, Barcellini W. SARS-CoV-2 Vaccination in Patients With Autoimmune Cytopenias: The Experience of a Reference Center. Am J Hematol (2021) 96(11):E413-6. doi: 10.1002/ajh.26345

54. Gadi SRV, Brunker PAR, Al-Samkari H, Sykes DB, Saff RR, Lo J, et al. Severe Autoimmune Hemolytic Anemia Following Receipt of SARS-CoV-2 mRNA Vaccine. Transfusion (2021) 61(11):3267-71. doi: 10.1111/trf.16672

55. Pérez-Lamas L, Moreno-Jiménez G, Tenorio-Núñez MC, Velázquez-Kennedy K, Jiménez-Chillón C, Astibia-Mahillo B, et al. Hemolytic Crisis Due to Covid- 19 Vaccination in a Woman With Cold Agglutinin Disease. Am J Hematol (2021) 96(8):E288-91. doi: 10.1002/ajh.26214

56. El-Sissy C, Saldman A, Zanetta G, Vieira-Martins P, Poulain C, Cauchois R, et al. COVID-19 as a Potential Trigger of Complement-Mediated Atypical HUS. Blood (2021) 138(18):1777-82. doi: 10.1182/blood.2021012752

57. Kaufeld JK, Reinhardt M, Schröder C, Bräsen JH, Wiech T, Brylka P, et al. Atypical HUS Triggered by Infection With SARS-Cov2. Kidney Int Rep (2021) 6(10):2709-12. doi: 10.1016/j.ekir.2021.07.004

58. Ville S, Le Bot S, Chapelet-Debout A, Blancho G, Fremeaux-Bacchi V, Deltombe C, et al. Atypical HUS Relapse Triggered by COVID-19. Kidney Int (2021) 99(1):267-8. doi: 10.1016/j.kint.2020.10.030

59. Simpson HD, Johnson E, Britton J, Braksick S. Alternating Hemiparesis in the Context of Hemolytic Uremic Syndrome and COVID-19 Positivity. Epilepsy Behav Rep (2021) 16:100468. doi: 10.1016/j.ebr.2021.100468

60. Barcellini W, Giannotta J, Fattizzo B. Autoimmune Hemolytic Anemia in Adults: Primary Risk Factors and Diagnostic Procedures. Expert Rev Hematol (2020) 13(6):585-97. doi: 10.1080/17474086.2020.1754791

61. Montagnani S, Tuccori M, Lombardo G, Testi A, Mantarro S, Ruggiero E, et al. Autoimmune Hemolytic Anemia Following MF59-Adjuvanted Influenza Vaccine Administration: A Report of Two Cases. Ann Pharmacother (2011) 45(1):e8. doi: 10.1345/aph.1P480

62. Gani I, Hinnant G, Kapoor R, Savage N. Autoimmune Hemolytic Anemia in a Renal Transplant Patient Following Seasonal Influenza Vaccination. Case Rep Hematol (2019) 2019:3537418. doi: 10.1155/2019/3537418
63. Green H, Eliakim-Raz N, Zimra Y, Gafter-Gvili A. Paroxysmal Nocturnal Hemoglobinuria Diagnosed After Influenza Vaccine: Coincidence or Consequence? Isr Med Assoc J (2014) 16(2):122-4.

64. Defendi F, Corentin L, Epaulard O, Clavarino G, Vilotitch A, Le MArechal M, et al. Complement Alternative and Mannose-Binding Lectin Pathway Activation Is Associated With COVID- 19 Mortality. Front Immunol (2021) 12:742446. doi: 10.3389/fimmu.2021.742446

65. Lipcsey M, Persson B, Eriksson O, Blom AM, Fromell K, Hultström M, et al. The Outcome of Critically Ill COVID-19 Patients Is Linked to Thromboinflammation Dominated by the Kallikrein/Kinin System. Front Immunol (2021) 12:627579. doi: 10.3389/fimmu.2021.627579

66. Cugno M, Meroni PL, Gualtierotti R, Griffini S, Grovetti E, Torri A, et al. Complement Activation in Patients With Covid-19: A Novel Therapeutic Target. J Allergy Clin Immunol (2020) 146:215-7. doi: 10.1016/ j.jaci.2020.05.006

67. Eriksson O, Persson B, Lipcsey M, Ekdahl K, Nilsson B. Mannose-Binding Lectin Is Associated With Thrombosis and Coagulopathy in Critically Ill COVID-19 Patients. Thromb Haemostasis (2020) 120(12):1720-4. doi: $10.1055 / \mathrm{s}-0040-1715835$

68. Eculizumab (Soliris) in Covid-19 Infected Patients (SOLID-C19). Available at: https://clinicaltrials.gov/ct2/show/NCT04288713 (Accessed 6th October 2021).

69. Conestat Alfa in the Prevention of Severe SARS-CoV-2 Infection in Hospitalized Patients With COVID-19. Available at: https://clinicaltrials.gov/ct2/show/ NCT04414631 (Accessed 6th October 2021).

70. A Study of the C3 Inhibitor AMY-101 in Patients With ARDS Due to COVID19 (SAVE). Available at: https://clinicaltrials.gov/ct2/show/NCT04395456 (Accessed 6th October 2021).

Conflict of Interest: The authors declare that the research was conducted in the absence of any commercial or financial relationships that could be construed as a potential conflict of interest.

Publisher's Note: All claims expressed in this article are solely those of the authors and do not necessarily represent those of their affiliated organizations, or those of the publisher, the editors and the reviewers. Any product that may be evaluated in this article, or claim that may be made by its manufacturer, is not guaranteed or endorsed by the publisher.

Copyright $\odot 2021$ Fattizzo, Pasquale, Bellani, Barcellini and Kulasekararaj. This is an open-access article distributed under the terms of the Creative Commons Attribution License (CC BY). The use, distribution or reproduction in other forums is permitted, provided the original author(s) and the copyright owner(s) are credited and that the original publication in this journal is cited, in accordance with accepted academic practice. No use, distribution or reproduction is permitted which does not comply with these terms. 